\title{
The chicken type III GnRH receptor homologue is predominantly expressed in the pituitary, and exhibits similar ligand selectivity to the type I receptor
}

\author{
Nerine T Joseph ${ }^{1,2}$, Kevin Morgan ${ }^{2}$, Robin Sellar ${ }^{2}$, Derek McBride ${ }^{1}$, Robert P Millar ${ }^{2,3}$ \\ and lan C Dunn ${ }^{1}$ \\ ${ }^{1}$ Royal (Dick) School of Veterinary Studies, The Roslin Institute, University of Edinburgh, Roslin, Midlothian, Edinburgh EH25 9PS, UK \\ ${ }^{2}$ MRC Human Reproductive Sciences Unit, The Queen's Medical Research Institute, Edinburgh EH16 4TJ, UK \\ ${ }^{3}$ MRC/UCT, Group for Receptor Biology, University of Cape Town, Cape Town 7925, South Africa \\ (Correspondence should be addressed to N T Joseph; Email: nerine.joseph@bbsrc.ac.uk)
}

\begin{abstract}
Two GnRH isoforms (cGnRH-I and GnRH-II) and two GnRH receptor subtypes (cGnRH-R-I and cGnRH-R-III) occur in chickens. Differential roles for these molecules in regulating gonadotrophin secretion or other functions are unclear. To investigate this we cloned cGnRH-R-III from a broiler chicken and compared its structure, expression and pharmacological properties with cGnRH-R-I. The broiler cGnRH-R-III cDNA was $100 \%$ identical to the sequence reported in the red jungle fowl and white leghorn breed. Pituitary cGnRH-R-III mRNA was $\sim 1400$-fold more abundant than cGnRH-R-I mRNA. Northern analysis indicated a single cGnRH-R-III transcript. A pronounced sex and age difference existed, with higher pituitary transcript levels in sexually mature females versus juvenile females. In contrast, higher expression levels occurred in juvenile males versus sexually mature males. Functional studies in COS-7

cells indicated that cGnRH-R-III has a higher binding affinity for GnRH-II than cGnRH-I $\left(K_{\mathrm{d}}: 0.57\right.$ vs $\left.19.8 \mathrm{nM}\right)$ with more potent stimulation of inositol phosphate production $\left(\mathrm{ED}_{50}: 0.8\right.$ vs $\left.4.38 \mathrm{nM}\right)$. Similar results were found for cGnRH-R-I, $\left(K_{\mathrm{d}}: 0.51 \mathrm{vs} 10.8 \mathrm{nM}\right)$ and $\left(\mathrm{ED}_{50}: 0.7 \mathrm{vs}\right.$ $2 \cdot 8 \mathrm{nM})$. The initial rate of internalisation was faster for cGnRH-R-III than cGnRH-R-I (26 vs $15 \cdot 8 \% / \mathrm{min}$ ). Effects of $\mathrm{GnRH}$ antagonists were compared at the two receptors. Antagonist \#27 distinguished between cGnRH-R-I and cGnRH-R-III ( $\mathrm{IC}_{50}: 2 \cdot 3$ vs $\left.351 \mathrm{nM}\right)$. These results suggest that cGnRH-R-III is probably the major mediator of pituitary gonadotroph function, that antagonist \#27 may allow delineation of receptor subtype function in vitro and in vivo and that tissue-specific recruitment of cGnRH-R isoforms has occurred during evolution.

Journal of Endocrinology (2009) 202, 179-190
\end{abstract}

\section{Introduction}

The hypothalamic decapeptide GnRH is a central regulator of reproductive function in vertebrates (Millar 2005). Two GnRH isoforms are present in the chicken; cGnRH-I and GnRH-II (Sharp \& Ciccone 2005). There is no genomic DNA evidence for a third GnRH ligand in the chicken to date. Both cGnRH-I and GnRH-II stimulate LH release from chicken pituitary in vitro (Hattori et al. 1986, Millar et al. 1986) and in vivo (Chou et al. 1985, Hattori et al. 1986, Sharp et al. 1986, Proudman et al. 2006). LH secretion in response to GnRH-II is markedly greater than that to cGnRH-I in mature laying hens. However, this is not the case in juvenile chickens of either sex, nor the cockerel (Sharp et al. 1987).

There is conflicting evidence for an effect of cGnRH-I or GnRH-II on FSH in vitro (Hattori et al. 1986, Millar et al. 1986), and in vivo (Krishnan et al. 1993, Bruggeman et al. 1998, Dunn et al. 2003, Proudman et al. 2006). Probably, cGnRH-I does not directly stimulate FSH release, but may stimulate FSH biosynthesis, while a role of GnRH-II in FSH production has not been established (Dunn et al. 2003, Sharp \& Ciccone 2005).

Immunisation of laying hens against cGnRH-I, but not against GnRH-II, results in a complete regression of the reproductive system and a decrease in plasma $\mathrm{LH}$ (Sharp et al. 1990), suggesting that gonadotrophin secretion is controlled by cGnRH-I rather than GnRH-II. This is consistent with the presence of $\mathrm{cGnRH}-\mathrm{I}$ in the median eminence (Mikami et al. 1988, Sharp et al. 1990) and the correlation between hypothalamic cGnRH-I peptide content and reproductive status (Sharp et al. 1990). In contrast, abundant levels of GnRH-II (Mikami et al. 1988, Sharp et al. 1990, Vangils et al. 1993) are not observed in the median eminence and no change in hypothalamic GnRH-II peptide content is seen in cockerels 
around the onset of puberty (Sharp et al. 1990). However, hypothalamic GnRH-II levels do decrease when the preovulatory release of $\mathrm{LH}$ is maximal or declining in the hen. Thus, GnRH-II may be involved in neuroendocrine events preceding ovulation (Wilson et al. 1990). In other avian species GnRH-II affects reproductive behaviour in ring doves and female soliciting behaviour in song sparrows (King \& Millar 1995, Maney et al. 1997).

The specific receptor types through which the GnRH ligands elicit biological responses in the chicken are not known. GnRH systems exhibit species-specific recruitment of receptor subtypes and ligands within different tissues. For example, the sea bass expresses five isoforms of $\mathrm{GnRH}$ receptor and all but one are expressed in the pituitary (Moncaut et al. 2005). In goldfish, two subtypes of the GnRH receptor have been identified (Illing et al. 1999) and they are both expressed in the pituitary. In the bullfrog, three subtypes of $\mathrm{GnRH}$ receptor are expressed but only one predominates in the pituitary (Wang et al. 2001). Two subtypes of GnRH receptor occur in the African clawed frog (Xenopus laevis; Troskie et al. 2000) whereas the leopard gecko expresses three receptor subtypes in the pituitary, with one receptor subtype predominating in the anterior pituitary (Ikemoto \& Park 2007). The pituitary-specific GnRH receptor subtypes expressed in the bullfrog (Wang et al. 2001), African clawed frog (Troskie et al. 2000) and leopard gecko (Ikemoto \& Park 2007) differ structurally, according to the nomenclature proposed by Miller et al. and phylogenetically (Millar et al. 2004, Flanagan et al. 2007, Tello et al. 2008). The predominant pituitary GnRH receptor subtype expressed in the bullfrog is type III, the African clawed frog is type I and the leopard gecko is type III. This suggests plasticity in evolutionary recruitment of $\mathrm{GnRH}$ receptor subtypes for regulation of pituitary gonadotrophin production. There is also plasticity in the spatiotemporal expression patterns of GnRH receptor subtypes (Illing et al. 1999, Troskie et al. 2000, Wang et al. 2001, Moncaut et al. 2005, Ikemoto \& Park 2007).

The promiscuity of receptor subtype activation by different endogenous GnRH ligands (Illing et al. 1999, Troskie et al. 2000, Wang et al. 2001, Moncaut et al. 2005, Ikemoto \& Park 2007) suggests that a complex interplay between ligands and receptors may occur. The organisation of the avian GnRH system is distinct from those of teleosts, amphibians, reptiles or mammals (Ensemble database), having two receptor subtypes for two GnRH ligands (Morgan \& Millar 2004). Further characterisation of the avian GnRH system may therefore provide unique information to enable further comprehension of the interplay between GnRH ligands and their receptors in the control of reproduction.

The first chicken GnRH-R isoform to be cloned, cGnRHR-I is widely expressed (Sun et al. 2001a,b) and GnRH-II has a higher binding affinity and is more potent in stimulating inositol phosphate accumulation than cGnRH-I at this receptor (Sun et al. 2001b). This suggested that the chicken pituitary might contain an alternative $\mathrm{GnRH}$ receptor more selective for cGnRH-I, since this appears to be the GnRH isoform most likely to be biologically important for regulation of LH production. A novel isoform of cGnRH-R was subsequently cloned by ourselves and others (Joseph et al. 2006, Shimizu \& Bedecarrats 2006; Genbank AY895154). The white Leghorn isoform of the novel receptor was designated cGNRHR2 (Shimizu \& Bedecarrats 2006), but it can be classified as a type III GnRH receptor. Using PCR, this receptor showed expression of two pituitary-specific transcripts (1260 bp full length and $1065 \mathrm{bp}$ splice variant; Shimizu \& Bedecarrats 2006), in addition to another $501 \mathrm{bp}$ splice variant that is expressed in different brain regions (Shimizu \& Bedecarrats 2006). Inositol phosphate accumulation in response to $\mathrm{GnRH}$-II stimulation was more potent at cGNRHR2 (Shimizu \& Bedecarrats 2006) than the response to cGnRH-I. Pituitary cGNRHR 2 mRNA expression levels correlated with reproductive status, suggesting that cGNRHR 2 plays a role in the regulation of gonadotroph function (Shimizu \& Bedecarrats 2006).

The aims of this study were to undertake further characterisation of this second GnRH receptor isoform from a broiler chicken (commercial meat-type chicken) and compare it with the type I receptor. Using bioinformatics analysis, we confirm that cGNRHR2 is a chicken type III $\mathrm{GnRH}$ receptor homologue. Critically, we have established the preponderance of cGNRHR2 mRNA relative to cGnRH-R-I mRNA in the pituitary and expression was investigated during sexual development and the levels were quantified in a panel of tissues. We also performed ligand induced internalisation studies of both receptors and a detailed pharmacological analysis of the two receptors. This included analysis of ligand binding and inositol phosphate production in response to cGnRH-I and GnRH-II and an array of analogues and antagonists in order to identify a GnRH analogue that may be applied to examine receptorspecific effects on gonadotrophin production.

\section{Materials and Methods}

\section{Animals}

Birds were killed in accordance with UK Home Office guidelines. Tissues were dissected, snap frozen in liquid nitrogen and stored at $-70{ }^{\circ} \mathrm{C}$.

\section{Peptides/primers}

GnRH analogues, cGnRH-I, GnRH-II and sGnRH-III (Sigma-Aldrich) and mammalian antagonists 27, 135-25 and 135-18 were diluted in 20\% propylene glycol (Sigma-Aldrich). Sequences are presented in Table 1. $\left[\mathrm{His}^{5}-\mathrm{D}-\mathrm{Tyr}^{6}\right]-\mathrm{GnRH}$ peptide was synthesised with solidphase methodology and purified by reverse-phase HPLC (Flanagan et al. 1998). Oligonucleotides (Sigma-Aldrich) diluted to $100 \mathrm{pM} / \mu \mathrm{l}$ were used for PCR amplification and probe synthesis. 
Table 1 Primary structure of GnRH analogues

Position of amino acid

\begin{tabular}{|c|c|c|c|c|c|c|c|c|c|c|c|}
\hline & 1 & 2 & 3 & 4 & 5 & 6 & 7 & 8 & 9 & 10 & \\
\hline \multicolumn{12}{|l|}{ Peptide name } \\
\hline GnRH-II & pGlu & His & Trp & Ser & His & Gly & Trp & Tyr & Pro & Gly & $\mathrm{NH}_{2}$ \\
\hline cGnRH-I & pGlu & $\mathrm{His}$ & Trp & Ser & Tyr & Gly & Leu & Gln & Pro & Gly & $\mathrm{NH}_{2}$ \\
\hline $\mathrm{His}^{5}$-D-Tyr ${ }^{6} \mathrm{GnRH}$ & pGlu & $\mathrm{His}$ & Trp & Ser & His & D-Tyr & Leu & Arg & Pro & Gly & $\mathrm{NH}_{2}$ \\
\hline sGnRH-III & pGlu & His & Trp & Ser & Tyr & Gly & Trp & Leu & Pro & Gly & $\mathrm{NH}_{2}$ \\
\hline 27 & AC-D Nal $(2)^{a}$ & D- $\alpha$-Me-4-Cl-Phe & D-Trp & Ser & Ipr-Lys & D-Tyr & Leu & Arg & Pro & D-Ála & $\mathrm{NH}_{2}$ \\
\hline $135-18$ & AC-D-Nal(2) & D-4-Cl-Phe & D-Pal(3) & Ser & Ile & D-Ipr-Lys & Leu & Ipr-Lys & Pro & D-Ala & $\mathrm{NH}_{2}$ \\
\hline $135-25$ & AC-D-Nal(2) & D-4-Cl-Phe & D-Pal(3) & Ser & 1-MePal & D-Ipr-Lys & Leu & Ipr-Lys & Pro & D-Ala & $\mathrm{NH}_{2}$ \\
\hline
\end{tabular}

${ }^{\mathrm{a}}$ Abbreviations for synthetic amino acids are: $\mathrm{Nal}(2), 3-(2-n a p h t h y l)$ alanine; 4-Cl-Phe, 3-(4-chlorophenyl) alanine; $\alpha$-Me-4-Cl-Phe, 2-methyl-3-(-chlorophenyl) alanine; Ipr-Lys, $N^{E}$-isopropyllysine.

\section{Cloning of $c$ GNRHR2 $c D N A$}

Trizol (Invitrogen) was used to isolate total RNA from pooled mature male and female anterior pituitary glands from broilers. cDNA synthesis was performed with $5 \mu \mathrm{g}$ total RNA using a first strand synthesis kit (Amersham Pharmacia Biotech Ltd). Genbank AY895154 was used as a reference for design of cDNA primers. Primers $1210 \mathrm{f}\left(5^{\prime}\right.$-TGAGTGGGCGGTGTTTGA-3') and $3217 \mathrm{r}$ (5'-TAGAGGCATTGTGGAGCAGA-3') encompassing the entire coding region of the receptor were used for PCR amplification of pituitary cDNA $\left(35\right.$ cycles of $95^{\circ} \mathrm{C} / 30 \mathrm{~s}$, $61.9{ }^{\circ} \mathrm{C} / 30 \mathrm{~s}, 72^{\circ} \mathrm{C} / 90 \mathrm{~s}$ ). The product was cloned into Bluescript II SK ${ }^{(+)}$vector (Stratagene, The Netherlands) at the EcoRV site. The entire cDNA insert was sequenced. To make an expression construct, the fragment between the BamHI and HincII restriction sites of the Bluescript II SK ${ }^{(+)}$ construct was removed and subcloned into the pCDNA3.1/ myc-His-A (Invitrogen) mammalian expression vector between the BamHI and EcoRV sites. The DNA sequence of the expression construct was verified by BamHI, BsmI and PstI restriction digest and sequencing.

An expression construct containing cGnRH-R-I cDNA cloned into pcDNA1/Amp (Invitrogen) eukaryotic expression vector was used (Sun et al. 2001b) in parallel studies.

\section{Oligonucleotide probes}

$5^{\prime}$ end labelling using $\left[\gamma_{-}{ }^{32} \mathrm{P}\right]$-dATP and T4 polynucleotide kinase was performed with 20 pmol sense (5'-TGGTGCCGATGTGGGAGCGCTGGGAGCAGTGAGTGGGCGGTGTT TGA- $3^{\prime}$ ) and anti-sense (5'-TCAAACACCGCCCACTCACTGCTCCCAGCGCTCCCACAT CGGCACCA-3') oligonucleotides using the mirVana Probe and Marker Kit (Ambion, USA). These oligonucleotides, designed in the $5^{\prime}$ region upstream of the translation start site in exon 1 are specific for cGNRHR 2 and are not homologous to cGnRH-R-I.

\section{$D N A$ probes}

An actin alpha-1 skeletal muscle (ACTA1; Genbank 001031063) DNA probe was synthesised from $0 \cdot 25 \mu \mathrm{g}$ purified insert DNA by random primer labelling with ${ }^{32} \mathrm{P}-\mathrm{dCTP}$ using a Rediprime Kit (GE Healthcare, UK) and purified using Sephadex G50 Nick columns (GE Healthcare).

\section{Riboprobes}

A riboprobe was synthesised by in vitro transcription of $1 \mu \mathrm{g}$ of the cGNRHR2 construct linearised with EcoRI using the T7 promoter and a kit (Promega) with ${ }^{[32 \mathrm{P}]} \mathrm{UTP}(800 \mathrm{Ci} /$ mmol, Amersham; specific activity of $30 \mathrm{TBq} / \mathrm{mmol}$ ). Free nucleotides were removed using a Sephadex G50 column (GE Healthcare).

\section{Northern blot analysis}

Ultraspec II (AMS Biotechnology Ltd, UK) was used to isolate total RNA from ten 14-week-old males of an advanced intercross of broiler and layer strain population. Poly $(\mathrm{A})^{+}$ RNA was purified from anterior pituitary gland, testes and small intestine total RNA using Oligotex mRNA SpinColumns (Qiagen). Three micrograms poly $(\mathrm{A})^{+}$RNA were loaded onto a formaldehyde gel and blotted using standard methodology.

Total RNA was also prepared from pituitary gland, brain cortex and skeletal muscle from sexually mature male and female white Leghorn layer type birds. Fifteen micrograms RNA were prepared for northern blotting according to the method of Pelle \& Murphy (1993).

\section{Tissue distribution of $c$ GNRHR 2 and quantification relative to} cGnRH-R-I

Total RNA was prepared from 3 male and 3 female, 6-week-old (pre-pubertal) Ross broiler type birds raised on $21 \mathrm{~h}$ light: $3 \mathrm{~h}$ darkness and 3 male and 3 female, 24-week-old 

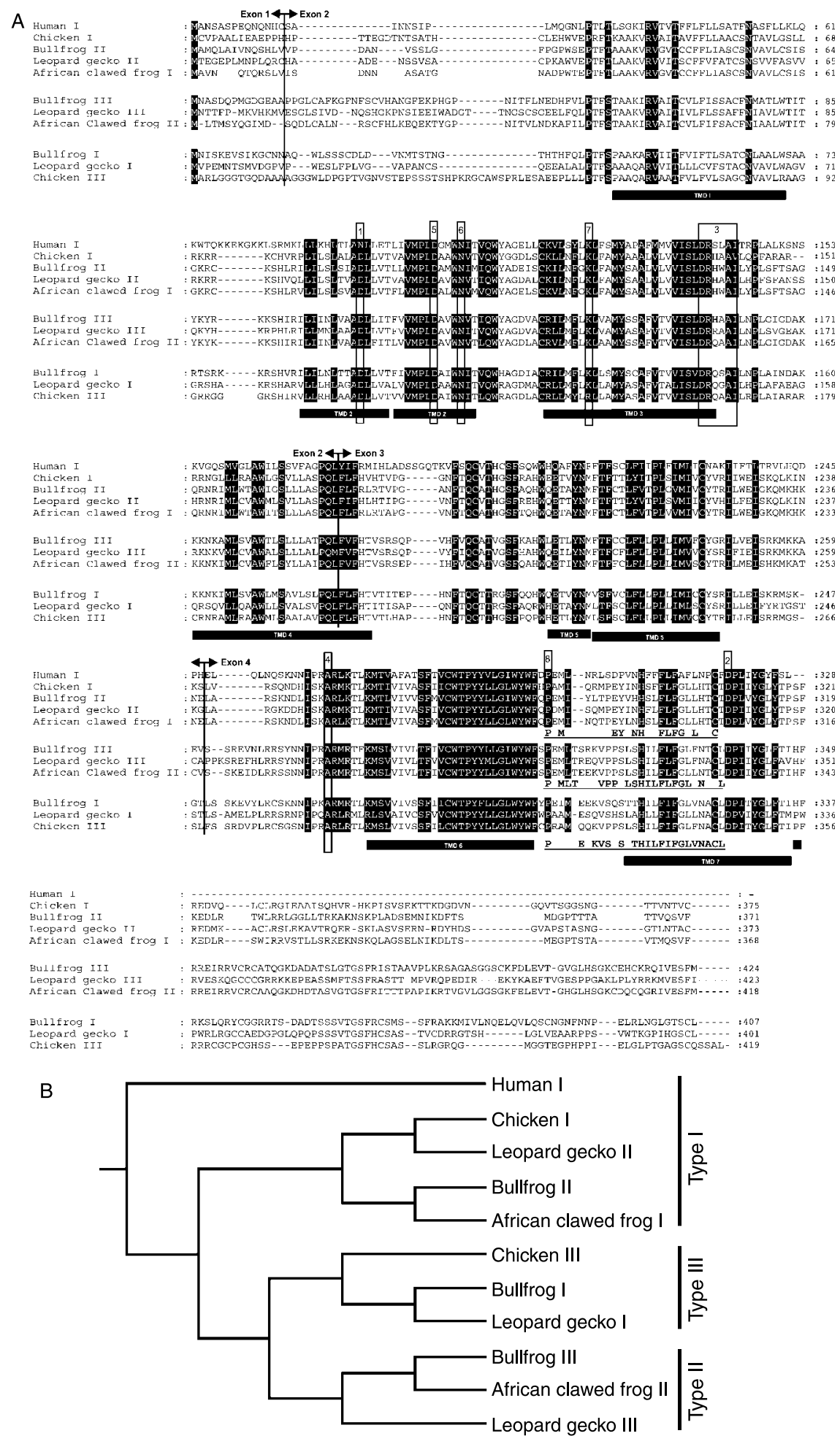
(sexually mature) Ross broiler breeder birds raised on $14 \mathrm{~h}$ light:10 h darkness. cDNA synthesis was performed on $0.5 \mu \mathrm{g}$ of total RNA, using a 1st Strand Synthesis Kit (Amersham Pharmacia Biotech Ltd). Primers that spanned exon boundaries, 713-735f (5'-GCTCGCTGTGCCGCAGCTGT-3'; exon 2-3) and 933-952r (5'-ACGTCCCTGGAGGAGAAGAG-3'; exon 3-4) were used to amplify cGNRHR2 from various tissue cDNA samples of the prepubertal males and females $\left(40\right.$ cycles of $95^{\circ} \mathrm{C} / 30 \mathrm{~s}$, $\left.62{ }^{\circ} \mathrm{C} / 30 \mathrm{~s}, 72{ }^{\circ} \mathrm{C} / 45 \mathrm{~s}\right)$. Real Time PCR was used to quantify the mRNA expression of cGnRH-R-I and cGNRHR 2 in the pituitary gland, median eminence, small intestine and gonad using the recommended amplification conditions using SYBR-Green-I-dye (Invitrogen). Primers that spanned the exon boundaries: $713-735 \mathrm{f}$ and $933-952 \mathrm{r}$ for cGNRHR 2 cDNA and primers 701-722f and 1100-1082r for cGnRH-R-I cDNA were used with pre-pubertal and sexually mature male and female tissue samples. Standard curves for amplification of each GnRH receptor homologue cDNA were made with known quantities of either chicken GnRH receptor cDNA. The cGNRHR2 cDNA in Bluescript II SK ${ }^{(+)}$vector and a cGnRH-R-I cDNA in Bluescript II $\mathrm{SK}^{(+)}$vector (containing $488 \mathrm{bp}$ inserted into the EcoRV/NotI site of the vector, which corresponds to bases 1-421 of AJ304414 and 1-68 of AJ506779) were used. A linear regression analysis of known quantities of cDNA template versus cycle threshold values was plotted, allowing the calculation of the quantity of target nucleic acid from the test-sample cycle threshold values. PCR reaction with either template reached plateau phase following the same number of amplification cycles.

\section{Iodination of $\left[H i s^{5}-D-T y r^{6}\right]-G n R H$}

$\left[\mathrm{His}^{5}\right.$-D-Tyr $\left.{ }^{6}\right]-\mathrm{GnRH}-\mathrm{I}$ peptide was radioactively labelled with Iodine $^{125}$ using Chloramine-T (Sigma-Aldrich) and purified using Sephadex G25 chromatography (Sigma-Aldrich).

\section{Cell culture and gene transfection}

COS-7 cells were transiently transfected by electroporation with $10 \mu \mathrm{g}$ expression construct. The cells were seeded in DMEM (Sigma-Aldrich) containing a final concentration of $10 \%$ FCS, $4 \mathrm{mM}$ L-glutamine and $1 \times$ penicillin/streptomycin and incubated in a humidified atmosphere at $37^{\circ} \mathrm{C}$ in $5 \% \mathrm{CO}_{2}$.

\section{Whole cell radioligand binding assay}

Radioligand binding assays were performed with ${ }^{125} \mathrm{I}-\left[\mathrm{His}^{5}\right.$ D-Tyr $\left.{ }^{6}\right]-G n R H-I$ on intact cells $48 \mathrm{~h}$ after transfection. Cells were washed twice with $4{ }^{\circ} \mathrm{C} \mathrm{PBS}+\mathrm{Ca}^{2+}+\mathrm{Mg}^{2+}$ (SigmaAldrich). The cells were then incubated for $4 \mathrm{~h}$ at $4{ }^{\circ} \mathrm{C}$ with ${ }^{125} \mathrm{I}_{-}\left[\mathrm{His}^{5}{ }^{5}-\mathrm{D}-\mathrm{Tyr}^{6}\right]-\mathrm{GnRH} \quad(100000$ c.p.m. $/ 500 \mu \mathrm{l})$ and various concentrations of unlabelled $\mathrm{GnRH}$ analogues in $25 \mathrm{mM}$ DMEM + HEPES + $0 \cdot 1 \%$ BSA in triplicate. Cells were then washed twice with $\mathrm{PBS}+\mathrm{Ca}^{2+}+\mathrm{Mg}^{2+}$ and lysed with $0.1 \mathrm{M} \mathrm{NaOH}$. Radioactivity was measured and non-specific binding was determined by displacement of label with $1 \mu \mathrm{M}$ unlabelled GnRH analogue.

\section{Inositol phosphate assay}

Total inositol phosphate accumulation in response to $\mathrm{GnRH}$ stimulation was analysed as previously described (Berg et al. 1994, Pawson et al. 2003) with modifications: $24 \mathrm{~h}$ after transfection, cells were labelled with $1 \mu \mathrm{Ci} / \mathrm{ml}$ per well $\left[{ }^{3} \mathrm{H}\right]$-myo-inositol, (Amersham Pharmacia Biotech) in $1 \mathrm{ml}$ of inositol-free DMEM (Invitrogen Life Sciences) and incubated for a further $24 \mathrm{~h}$. Cells were incubated at $37^{\circ} \mathrm{C}$ with $0.5 \mathrm{ml} 25 \mathrm{mM}$ DMEM + HEPES (SigmaAldrich) containing $10 \mathrm{mM} \mathrm{LiCl}$ for two successive 5 and 30 min washes prior to stimulation with $\mathrm{GnRH}$ analogue in DMEM + HEPES + $10 \mathrm{mM} \mathrm{LiCl}$ for $1 \mathrm{~h}$. Antagonist activity was assayed in the presence of $1 \mathrm{nM}$ GnRH-II. Stimulations were terminated by replacing medium with $10 \mathrm{mM}$ formic acid and incubating at $4{ }^{\circ} \mathrm{C}$ for $1 \mathrm{~h}$. Watersoluble metabolites were separated as previously described (Berridge et al. 1983) with a series of washes of the Dowex resin with $\mathrm{H}_{2} \mathrm{O}$ and $60 \mathrm{mM}$ ammonium formate, $5 \mathrm{mM}$ sodium tetraborate prior to inositol phosphate elution in $1 \mathrm{M}$ ammonium formate, $0 \cdot 1 \mathrm{M}$ formic acid. Assays were performed in triplicate.

\section{Receptor internalisation assays}

Receptor-transfected cells were incubated for $48 \mathrm{~h}$ prior to performing the internalisation assay as previously described (Pawson et al. 1998). Modifications to the protocol included addition of $0.5 \mathrm{ml}$ acid solution $(150 \mathrm{mM} \mathrm{NaCl}, 50 \mathrm{mM}$ acetic acid, $\mathrm{pH} 2 \cdot 8$ ) to determine surface bound ligand and $0.5 \mathrm{ml} 1 \mathrm{M} \mathrm{NaOH}$ for internalised radioligand.

\footnotetext{
Figure 1 (A) Alignment of human, bullfrog, leopard gecko, African clawed frog and chicken GnRH receptor sequences. These are representative sequences of GnRH receptor types I, II and III. Motifs in ECL3 are depicted in bold and underlined. Ubiquitously conserved amino acid residues are shown with dark background shading. Boxed amino acids are as follows: 1 and 2, aspartic acid in the functional helix2/helix7 micro-domain of non-mammalian GnRH receptors; 3 and 4, conserved coupling arginine cage motif and alanine; 5, 6, 7 and 8, ligand binding residues, aspartic acid, asparagine, lysine and arginine respectively. Predicted transmembrane domains (TMD1-7) are indicated by a bold line. GnRH receptor subtypes are labelled according to the published terminology and presented in Roman numerals (Wang et al. 2001, Ikemoto \& Park 2007). (B) A phylogenetic tree based on multiple sequence alignment of representative, reptilian, amphibian and avian $\mathrm{GnRH}$ receptor sequences. The tree was constructed using TreeTop phylogenetic tree prediction software (Yushmanov \& Chumakov 1988).
} 
Non-specifically bound ligand was measured at time point zero and used to normalise data. Assays were performed four times with six replicate points per experiment.

\section{Statistical analysis}

ANOVA was performed on Real time PCR data using GenStat version 9 (VSN International Ltd, UK). Other results were analysed using GraphPad Prism version 4.0 (GraphPad Software, CA, USA). Non-linear regression models were applied to the ligand binding and inositol phosphate assay data. Receptor internalisation rates were analysed as previously described (Pawson et al. 1998).

\section{Results}

\section{Cloning of the cGNRHR2 $c D N A$}

We cloned a PCR cDNA product from broiler (meat-type birds) pituitary samples that was identical to the sequence from Gallus gallus gallus genomic DNA (ENSGALG00000020923; Ensembl 2004) and White Leghorn strains (Genbank AY895154). An expression construct containing the entire coding sequence, $24 \mathrm{bp} 5^{\prime}$ to the start codon and $100 \mathrm{bp} 3^{\prime}$ to the stop codon was prepared.

\section{Gene structure of $c$ GNRHR2}

Bioinformatic comparisons of the cDNA and genomic DNA sequences confirmed that the receptor consists of a 419 amino acid protein encoded by 4 exons (Shimizu \& Bedecarrats 2006) on chicken chromosome 10 linked to the type I receptor. The amino acid sequence identity of the two cGnRH-Rs is $53 \%$ (Fig. 1A). The amino acid sequences of both cGnRH-R receptors were compared with human, bullfrog, leopard gecko and African clawed frog $\mathrm{GnRH}$ receptor subtypes. The highest homology to cGnRH-R-I was with bullfrog-II GnRH-R. The highest homology to cGNRHR2 occurred with bullfrog-I and leopard gecko-I GnRH-Rs. Phylogenetic analysis performed by ourselves (Fig. 1B) and others (Flanagan et al. 2007, Tello et al. 2008) clearly classes this receptor as a type III GnRH receptor homologue. We therefore refer to it as cGnRH-R-III from here on.

The putative translation start codon is coded by exon 1 and the stop codon by exon 4. The amino terminal extracellular domain is coded by exon 1 and exon 2. Exon 2 also encodes transmembrane domain (TMD) 1, intracellular loop (ICL) 1, TMD2, extracellular loop (ECL) 1, TMD3, ICL2 and part of TMD4. Exon 3 encodes the rest of TMD4, ECL2, TMD5 and part of ICL3. Exon 4 encodes the rest of ICL3, TMD6, ECL3, TMD7 and the C-terminal cytoplasmic domain (Fig. 1A).

Comparisons of functionally important residues and micro-domains were performed. cGnRH-R-III like cGnRH-R-I has aspartic acid in both loci of the helix $2 /$ helix7 micro-domain, an arrangement unique to non-mammalian GnRH receptors (Zhou et al. 1994, Flanagan et al. 1999; Fig. 1A). Conservation of important coupling motifs, the arginine cage motif (Ballesteros et al. 1998) and alanine in ICL3 (Myburgh et al. 1998) is maintained in cGnRH-R-III (Fig. 1A). The two cGnRHRs exhibit conservation of the aspartic acid (Flanagan et al. 2000) and asparagine (Davidson et al. 1996) ligand-binding residues in TMD2 (Fig. 1A). The lysine in TMD3 of the cGnRH-R-III (Zhou et al. 1995) is substituted with an arginine residue. The glutamate residue in ECL3 (Flanagan et al. 1994) is not conserved in cGnRH-R-III whereas it is in cGnRH-R-I (Sun et al. 2001b). ECL3 of each receptor type has a distinctive classification motif (Millar et al. 2004), cGnRH-R-I has a PEY motif in ECL3 whereas in cGnRH-R-III this motif is PPS (Fig. 1A). The motifs known to be crucial for receptor internalisation were compared (Pawson et al. 1998, 2003), and are conserved between cGnRH-R-I and cGnRH-R-III, however, the tail of cGnRH-R-III is longer by an additional eight residues (Fig. 1A).

\section{Northern blot analysis}

Hybridisation of cGnRH-R-III antisense oligonucleotide probe was detected in the anterior pituitary but not testes or small intestine RNA (Fig. 2A). The cGnRH-R-III mRNA transcript is approximately 1600 bases long. Sense oligonucleotides did not hybridise to the RNA samples (data not shown). ACTA1 skeletal muscle ${ }^{32} \mathrm{P}-\mathrm{dCTP}$ labelled DNA probe hybridised to all samples (Fig. 2B), demonstrating equal RNA loading. A riboprobe also detected cGnRH-R-III mRNA transcripts of approximately 1600 bases in male and female anterior pituitary but not brain cortex or skeletal muscle RNA (Fig. 2C). There was no evidence of cGnRH-R-III mRNA transcript size variants in any tissues.

\section{Tissue distribution of cGnRH-R-III expression and quantification relative to $c \mathrm{GnRH}-\mathrm{R}-\mathrm{I}$}

PCR amplification of GnRH receptor cDNA was ensured by designing primers spanning exon boundaries. A single $238 \mathrm{bp}$ cDNA amplification product derived from exon 3 was detected in the pituitary. Amplification of cGnRH-R-III cDNA was detected in all tissues tested (anterior pituitary, hind-brain, cerebrum, cerebellum, median eminence, anterior hypothalamus, posterior hypothalamus, olfactory bulb, optic lobe, adrenal gland, kidney, small intestine, spleen, testes, ovary and liver) from pre-pubertal males and females although the signal intensity in the anterior pituitary was distinctly the highest. Relative levels of cGnRH-R-I and cGnRH-R-III mRNA measured by real-time PCR in juvenile and mature male and female tissues demonstrated that expression of cGnRH-R-III was greater than $\mathrm{cGnRH}-$ R-I in the pituitary, median eminence, gonads and small intestine. In the anterior pituitary cGnRH-R-III expression was 1373 -fold that of cGnRH-R-I (Fig. 2F). Even though 

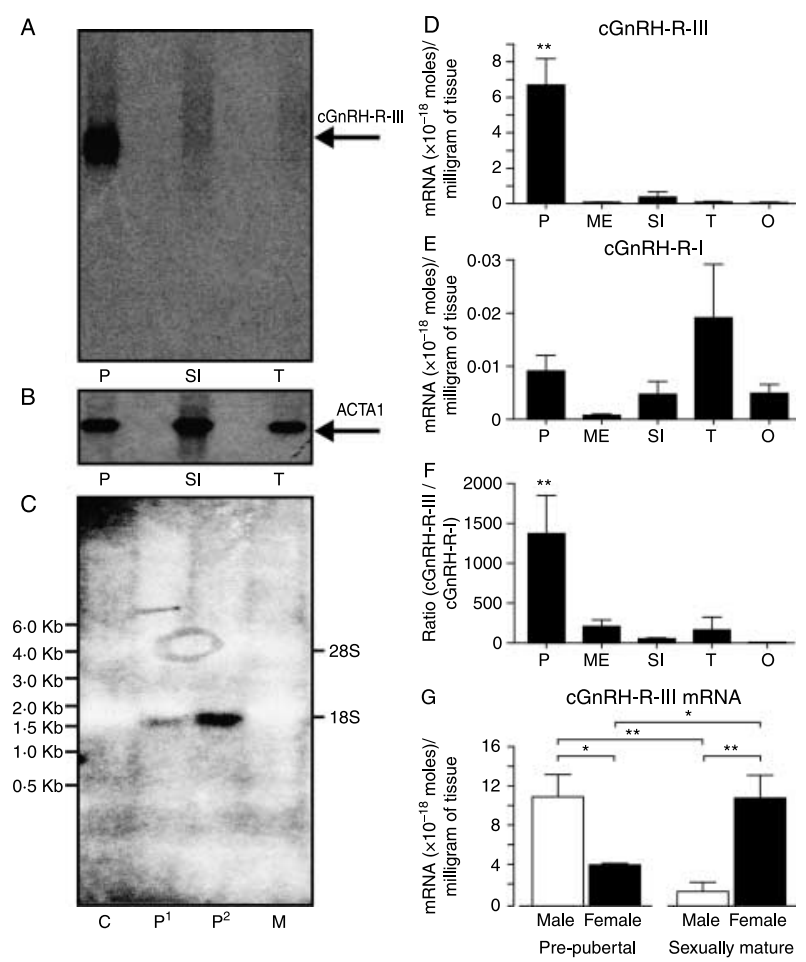

Figure 2 Northern blot of pituitary $(\mathrm{P})$, small intestine (SI) and testes (T) Poly (A) ${ }^{+}$RNA samples from 14-week-old AIL male birds, hybridised with (A) cGnRH-R-III $\left[\gamma_{-}{ }^{32} \mathrm{P}\right]-$ dATP $5^{\prime}$ end labelled oligoprobe and (B) actin alpha skeletal muscle (ACTA1) ${ }^{32} \mathrm{P}-\mathrm{dCTP}$ random primer labelled DNA probe. (C) Northern blot with pooled male and female cortex $(C)$, pooled male and female muscle $(M)$ and anterior pituitary glands $\left(\mathrm{P}^{1}=\right.$ female, $\mathrm{P}^{2}=$ male) total RNA samples from white Leghorn layer type birds, hybridised with GnRH-R-III antisense riboprobe covering all four exons. The blot shows a single band in the pituitaries and no detectable bands in the muscle or cortex tissues. RNA size markers were run on the original gel and sizes were transferred to the image by interpolation. The position of the $28 \mathrm{~S}$ and $18 \mathrm{~S}$ rRNA is indicated and can be seen as areas of reduced background on the image. (D-F) Comparative quantitative real-time PCR analysis of cGnRH-R-I and cGnRH-R-III mRNA expression in tissues of pre-pubertal and sexually mature, male and female broiler chickens. (D) cGnRH-R-III mRNA expression per milligram of tissue. (E) cGnRH-R-I mRNA expression per milligram of tissue. (F) Ratio of absolute expression of CGnRH-R-III over cGnRH-R-I mRNA. Values are mean $(\mathrm{mol} / \mathrm{mg}) \pm$ s.E.M., ${ }^{* *} P \leq 0 \cdot 01$. $\mathrm{P}$, pituitary; ME, median eminence; $\mathrm{SI}$, small intestine; $\mathrm{T}$, testes; $\mathrm{O}$, ovary. (No significant differences were detected between male and female gonads). (G) Relationship between sex and age on pituitary cGnRH-R-III mRNA expression in pre-pubertal $(n=6)$ and sexually mature $(n=6)$, male $(n=6$; open columns) and female $(n=6$; solid columns) broiler chickens. Values are mean $(\mathrm{mol} / \mathrm{mg}) \pm$ s.E.M., ${ }^{*} P \leq 0 \cdot 05,{ }^{* *} P \leq 0 \cdot 01$.

the amplification efficiency of the two targets was similar, higher cGnRH-R-III expression was detected in the anterior pituitary compared with the median eminence, gonads and small intestine (Fig. 2D). Anterior pituitary expression of cGnRH-R-III was $92.5 \times$ greater than in the testes or ovary. Expression of cGnRH-R-I in the testes was 2-fold greater than in the anterior pituitary (Fig. 2E).
ANOVA demonstrated a significant relationship between age and sex on pituitary cGnRH-R-III expression (Fig. 2G). Anterior pituitary cGnRH-R-III expression was $8 \cdot 4$-fold lower in sexually mature males compared with juvenile males whereas the reciprocal relationship was observed in females, with $2 \cdot 8$-fold more anterior pituitary cGnRH-R-III expression in sexually mature females compared with juveniles (Fig. 2G).

\section{Whole cell GnRH binding assays}

Cells transfected with cGnRH-R-III and cGnRH-R-I expression constructs showed binding and displacement of ${ }^{125} \mathrm{I}-\left[\mathrm{His}^{5}\right.$-D-Tyr $\left.{ }^{6}\right]-\mathrm{GnRH}$ with both cGnRH-I and GnRH-II in a concentration dependant fashion. The binding affinities for cGnRH-I and GnRH-II were similar at cGnRH-R-I and cGnRH-R-III (Fig. 3A). cGnRH-R-III exhibited a 35-fold higher affinity for GnRH-II than for cGnRH-I (Table 2). cGnRH-R-I exhibited a 21-fold higher affinity for GnRH-II than for cGnRH-I, similar to previous reports (Sun et al. 2001b).

cGnRH-R-III and cGnRH-R-I bound sGnRH-III and mammalian antagonists 27, 135-18 and 135-25 (Table 2). Because there was no genomic evidence for GnRH-III in the chicken, the binding affinity for sGnRH-III was tested as an alternative. cGnRH-R-III and cGnRH-R-I exhibited a 16-fold higher affinity for GnRH-II than for sGnRH-III, and both receptors exhibited a higher affinity for sGnRH-III than cGnRH-I (Table 2). Similar binding affinities were observed for all GnRH analogues and mammalian antagonists at either receptor except for mammalian antagonist 27.

cGnRH-I, GnRH-II, sGnRH-III, mammalian antagonist 135-18 and 135-25 showed respectively a $1 \cdot 8,1 \cdot 1,1 \cdot 1,3 \cdot 5$ and $0 \cdot 6$-fold higher binding affinity at cGnRH-R-I compared with cGnRH-R-III. Remarkably, cGnRH-R-I has a much higher affinity for mammalian antagonist $27\left(K_{\mathrm{d}}\right.$ : $0 \cdot 38 \mathrm{nM})$ than cGnRH-R-III $\left(K_{\mathrm{d}}: 21 \cdot 4 \mathrm{nM}\right)$.

\section{Inositol phosphate assays}

cGnRH-I and GnRH-II stimulated inositol phosphate production in cGnRH-R-I and cGnRH-R-III transfected cells (Fig. 3B). The $\mathrm{ED}_{50}$ for GnRH-II was much lower than for $\mathrm{CGnRH}-\mathrm{I}$, in accordance with their binding affinities. GnRH-II was more potent than cGnRH-I at either receptor. In cGnRH-R-III transfected cells, the accumulation of inositol phosphate was six times more effective with GnRH-II stimulation than with cGnRH-I (Table 2). GnRH-II was four times more potent than cGnRH-I for production of inositol phosphate via activation of cGnRH-R-I (Table 2). The $\mathrm{ED}_{50}$ for sGnRH-III was much higher than GnRH-II and cGnRH-I at both cGnRH-Rs (Table 2). In response to cGnRH-I, GnRH-II or sGnRH-III there was a $1 \cdot 6,1 \cdot 1$ and $2 \cdot 0$-fold higher potency at cGnRH-R-I compared with cGnRH-R-III. 

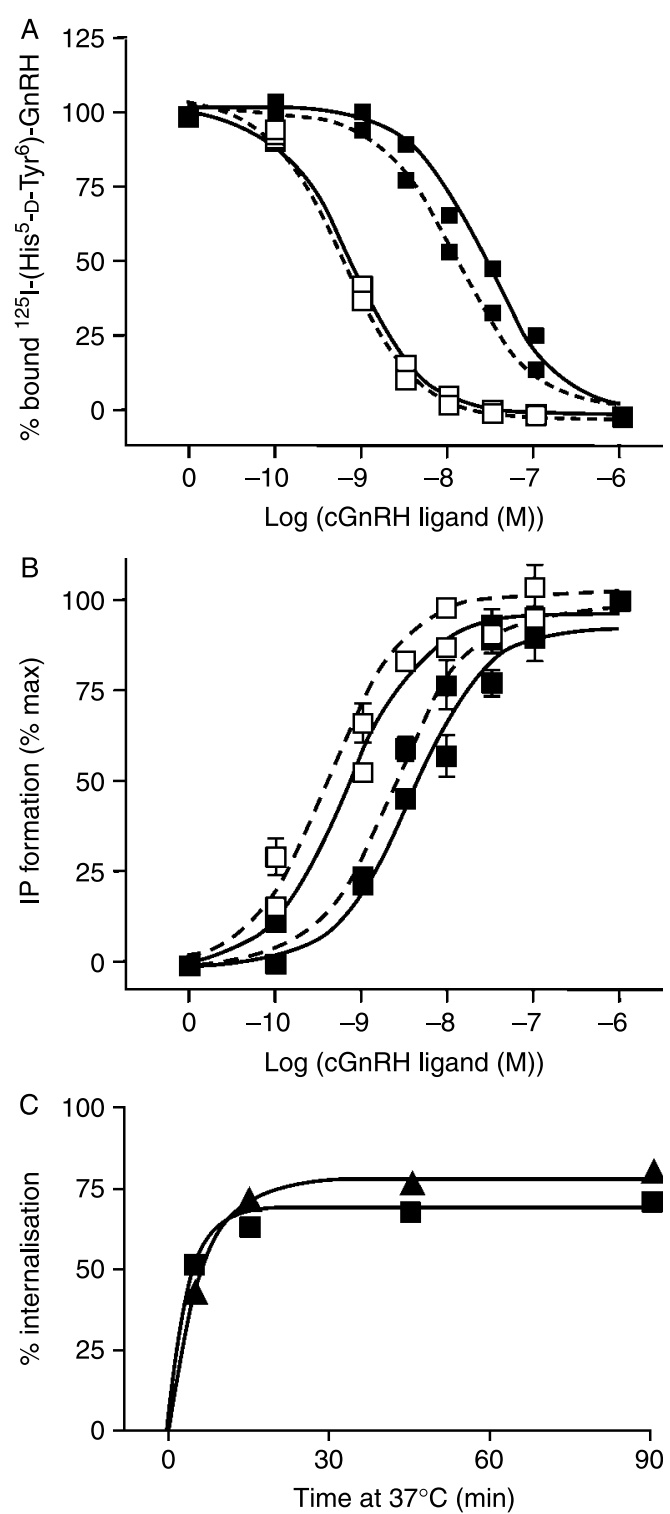

Figure 3 (A) Ligand binding of cGnRH-R-I and cGnRH-R-III. Competitive displacement of ${ }^{125} \mathrm{I}-\left[\mathrm{His}^{5}-\mathrm{D}-\mathrm{Tyr}^{6}\right]-\mathrm{GnRH}$ with serial dilutions $\left(10^{-11}-10^{-6} \mathrm{M}\right)$ of CGnRH-I (solid squares) and $\left(10^{-11}-10^{-6} \mathrm{M}\right) \mathrm{GnRH}-\mathrm{II}$ (open squares) in COS-7 cells transiently transfected with cGnRH-R-I (dashed lines) and cGnRH-R-III (solid lines) expression constructs. The data presented are from four independent experiments each performed in triplicate. Non-specific binding, determined in un-transfected cells was subtracted from c.p.m. (B) Inositol phosphate production in response to $\left(10^{-11}-10^{-6} \mathrm{M}\right) \mathrm{CGnRH}-\mathrm{I}$ (solid squares) and GnRH-II (open squares) in COS-7 cells transiently transfected with cGnRH-R-I (dashed lines) and cGnRH-R-III (solid lines) expression constructs. The data are from four independent experiments performed in triplicate. (C) $\mathrm{CGnRH}-\mathrm{R}-\mathrm{I}$ and $\mathrm{CGnRH}-\mathrm{R}-\mathrm{III}$ ligand induced internalisation rate. Per cent internalisation of ${ }^{125} \mathrm{I}-\left[\mathrm{His}^{5}-\mathrm{D}-\mathrm{Tyr} \mathrm{r}^{6}\right]-\mathrm{GnRH}$ ligand mediated by cGnRH-R-I (solid triangle) and cGnRH-R-III (solid square). Data points are the mean \pm S.E.M. of four independent experiments each performed with six replicates. Non-specific binding, determined in un-transfected cells was accounted for.
Mammalian antagonist 27 displayed inverse agonist properties at either receptor, decreasing inositol phosphate production below basal levels for both receptors (Fig. 4A and C). Mammalian antagonist 135-25 stimulated inositol phosphate production with very low efficacy in transfected COS-7 cells: cGnRH-R-I (ED 50 : $5970 \mathrm{nM}$ ) and cGnRH-R-III $\left(\mathrm{ED}_{50}\right.$ : $4860 \mathrm{nM}$; Table 2 and Fig. 4E and G). Mammalian antagonist 135-18 stimulated inositol phosphate in transfected COS-7 cells; cGnRH-R-III (ED $50: 1510 \mathrm{nM}$ ) with weak efficacy, but no stimulation of inositol phosphate was detected in cGnRH-R-I transfected cells (Fig. 4I and K).

Inhibition of $1 \mathrm{nM}$ GnRH-II-stimulated inositol phosphate production by mammalian antagonist 135-18 in cGnRH-R-I transfected COS-7 cells ( $\left.\mathrm{IC}_{50}: 2330 \mathrm{nM}\right)$ was more potent than for cGnRH-R-III ( $\left.\mathrm{IC}_{50}: 3890 \mathrm{nM}\right)$ transfected COS-7 cells (Fig. 4J and L). Mammalian antagonist 135-25, acted as a pure agonist in cGnRH-R-III transfected cells in the presence of $1 \mathrm{nM}$ GnRH-II, increasing the potency of inositol phosphate stimulation from $\mathrm{ED}_{50}$ : $4860 \mathrm{nM}$ in the absence of GnRH-II to $\mathrm{ED}_{50}: 20 \cdot 1 \mathrm{nM}$ in the presence of GnRH-II (Fig. 4H). Antagonistic properties for mammalian antagonist 135-25 were observed at cGnRH-R-I ( $\mathrm{IC}_{50}$ : $\left.245 \mathrm{nM}\right)$ transfected cells, but with little efficacy (Fig. 4F). Surprisingly, mammalian antagonist 27 exhibited large differences in antagonistic potency at cGnRH-R-I (IC50: $2 \cdot 3 \mathrm{nM}$ ) compared with cGnRH-R-III $\left(\mathrm{IC}_{50}: 351 \mathrm{nM}\right.$; Fig. $4 \mathrm{~B}$ and D).

\section{Receptor internalisation assays}

The initial rate of internalisation of ${ }^{125} \mathrm{I}-\left[\mathrm{His}^{5}-\mathrm{D}-\mathrm{Tyr}^{6}\right]-$ GnRH-I bound to cGnRH-R-III was slightly greater $(P<0.006)$ than cGnRH-R-I. cGnRH-R-I internalised at an initial rate of $15.8 \% / \mathrm{min}$ whereas the initial rate of internalisation of cGnRH-R-III was determined as $26.0 \% / \mathrm{min}$. The per cent maximal internalisation of cGnRH-R-I was $78 \cdot 2$ vs $68 \cdot 9 \%$ for GnRH-R-III (Fig. 3C).

\section{Discussion}

Birds, like mammals, possess two GnRH receptor subtypes in contrast to fish, reptiles and amphibians in which three types of receptor are generally found (Morgan \& Millar 2004, Ikemoto \& Park 2007). The proximity of the two chicken receptor subtypes on chromosome $10(\sim 2 \mathrm{Mb}$ apart $)$ and their high sequence similarity, suggests they may have been derived by gene duplication.

There has been an inclination to designate $\mathrm{GnRH}$ receptors that are selective for GnRH-II as type II GnRH receptors. However, all non-mammalian receptors, regardless of their structural similarity are selective for GnRH-II (Pfleger et al. 2002). Other investigators have designated GnRH receptors by their tissue-specific expression. This classification is also problematic as the predominant $\mathrm{GnRH}$ 
Table 2 Receptor binding and peptide-stimulated inositol phosphate accumulation in response to cGnRH analogues in COS-7 cells expressing CGnRH-R-I and cGnRH-R-III

\begin{tabular}{|c|c|c|c|c|c|c|}
\hline \multirow[b]{4}{*}{$\begin{array}{l}\text { Analog } \\
\text { CGnRH-I }\end{array}$} & \multicolumn{2}{|l|}{ Ligand binding } & \multicolumn{4}{|l|}{ IP production } \\
\hline & \multirow{2}{*}{$\begin{array}{l}\mathrm{cGnRH}-\mathrm{R}-\mathrm{I} \\
K_{\mathrm{i}}(\mathrm{nM})^{\mathrm{a}}\end{array}$} & \multirow[t]{2}{*}{ cGnRH-R-III } & \multicolumn{2}{|l|}{ cGnRH-R-I } & \multicolumn{2}{|l|}{ CGnRH-R-III } \\
\hline & & & $\mathrm{ED}_{50}(\mathrm{nM})^{\mathrm{b}}$ & $\mathrm{IC}_{50}(\mathrm{nM})^{\mathrm{C}}$ & $\overline{\mathrm{ED}_{50}(\mathrm{nM})^{\mathrm{b}}}$ & $\mathrm{IC}_{50}(\mathrm{nM})^{\mathrm{C}}$ \\
\hline & $10 \cdot 8 \pm 1 \cdot 59^{d}$ & $19 \cdot 8 \pm 3 \cdot 56^{\mathrm{d}}$ & $2 \cdot 8 \pm 0 \cdot 20^{d}$ & & $4 \cdot 38+0 \cdot 18^{\mathrm{d}}$ & \\
\hline GnRH-II & $0.51 \pm 0.07^{\mathrm{d}}$ & $0.57 \pm 0.15^{d}$ & $0 \cdot 7 \pm 0 \cdot 14^{d}$ & & $0 \cdot 8 \pm 0 \cdot 14^{\mathrm{d}}$ & \\
\hline sGnRH-III & $8 \cdot 40 \pm 1 \cdot 21^{\mathrm{e}}$ & $9 \cdot 31 \pm 4 \cdot 31^{\mathrm{e}}$ & $10 \cdot 3 \pm 4 \cdot 5^{\mathrm{d}}$ & & $21 \pm 0 \cdot 2^{\mathrm{d}}$ & \\
\hline & $0.38 \pm 0.09^{\mathrm{e}}$ & $21 \cdot 4 \pm 4 \cdot 86^{\mathrm{e}}$ & Inverse agonist $\mathrm{e}^{-}$ & $2 \cdot 3 \pm 0 \cdot 3^{\mathrm{e}}$ & Inverse agonist $\mathrm{e}^{-}$ & $351 \pm 114^{\mathrm{e}}$ \\
\hline $135-18$ & $2090 \pm 156^{\mathrm{e}}$ & $7260 \pm 105^{\mathrm{e}}$ & None $^{\mathrm{d}}$ & $2330 \pm 134^{d}$ & $1510 \pm 216^{\mathrm{d}}$ & $3890 \pm 2027^{d}$ \\
\hline $135-25$ & $14200 \pm 1515^{\mathrm{e}}$ & $8560 \pm 3402^{\mathrm{e}}$ & $5970 \pm 2510^{d}$ & $245 \pm 207^{\mathrm{d}}$ & $4860 \pm 807^{\mathrm{d}}$ & None $e^{d, t}$ \\
\hline
\end{tabular}

All experiments were performed on separate occasions in triplicate.

${ }^{\mathrm{a}} K_{\mathrm{i}}$ values (binding affinities) for $\mathrm{GnRH}$ analogues.

${ }^{\mathrm{b}} \mathrm{ED}_{50}$ values for agonist activity of $\mathrm{GnRH}$ analogues.

${ }^{{ }^{1} C_{50}}$ values for antagonism of IP production stimulated by $1 \mathrm{nM}$ GnRH-II.

${ }^{\mathrm{d}}$ Data are mean \pm S.E.M. of three to four experiments.

e Data are mean \pm S.E.M. of two to three experiments.

${ }^{f} 20 \cdot 1 \pm 8 \cdot 9=$ agonistic effect of peptide in presence of $1 \mathrm{nM} \mathrm{GnRH-II}$.

receptor expressed in bullfrog pituitary is structurally a type III receptor (Wang et al. 2001) while in African clawed frog, it is a type I receptor (Troskie et al. 2000). We therefore advocate that the receptors are grouped and designated according to their structural and phylogenetic relatedness. cGnRH-R-III was first designated as cGNRHR2 (Shimizu \& Bedecarrats 2006), whereas designation as cGnRH-R-III is appropriate according to phylogenetic classification.

Delineation of 'cognate' ligand/receptor pairing requires the demonstration of receptor protein expression in the target cell and demonstration of ligand isoform delivery to that cell. In the chicken there is good evidence (Mikami et al. 1988, Sharp et al. 1990, Vangils et al. 1993) that cGnRH-I targets the gonadotroph and the higher expression levels of GnRH-R-III in the pituitary suggest that it is the cognate pituitary receptor. Expression of cGnRH-R-III was 1373 -fold higher than cGnRH-R-I in the anterior pituitary gland. However, GnRH-R-III localisation to the gonadotroph remains to be demonstrated. Therefore, the development of analogues that differentially promote or inhibit activation of receptor subtypes may be valuable tools for deciphering the role of receptor types in terms of gonadotrophin regulation or other putative functions.

No sex differences or changes in expression were detected for cGnRH-R-I, however, a pronounced reciprocal sex difference in pituitary cGnRH-R-III expression was observed. Higher cGnRH-R-III mRNA levels occur in adult females compared with adult males. In contrast, in juvenile chickens, higher cGnRH-R-III mRNA levels occurred in males compared with females. cGnRH-R-III splice variant transcripts detected by PCR amplification (Shimizu \& Bedecarrats 2006) were not detected by oligonucleotide probe or riboprobe using northern blotting, suggesting that their in vivo expression is relatively low and may be of little functional significance.

Differences in cGnRH-R-III receptor expression levels between juvenile and mature males and females were not reported previously (Shimizu \& Bedecarrats 2006). This may be due to the age of animals used in different studies. The sexual dimorphism in cGnRH-R-III expression, where levels of mRNA are higher in juvenile males compared with juvenile females, is consistent with the LH response to photostimulation seen in juveniles, where there is a robust response in males but not in females (Sreekumar \& Sharp 1998). However, in adult males and females, cGnRH-R-III expression levels are inversely related to sex differences in LH responsiveness to GnRH injection (Sharp et al. 1987). When chicken pituitary fragments from adult males and juveniles of both sexes are perifused, a large spike followed by a plateau in LH release in response to GnRH stimulation is observed (Liu et al. 1995). Adult laying hens do not exhibit the rapid spike of release but do show the plateau phase and the release of LH in adult hens is much reduced compared with juvenile hens (Liu et al. 1995). In general, our observations suggest that the level of GnRH-R-III mRNA may be inversely related to the release of $\mathrm{LH}$ by gonadotrophs in adult females. There are several possible explanations for this apparent paradox. However, cGnRH-R-III mRNA may be reflective of expression of membrane cGnRH-R-III receptor number, but that increased ovarian steroid and peptide hormones act negatively in the adult female to diminish the LH response to GnRH at the gonadotroph, through down-regulation of intercellular signalling pathways including the $\mathrm{Ca}^{2+}$ mobilisation mechanism (Liu et al. 1995).

As noted above, the occurrence of two or three forms of GnRH peptide hormone in different vertebrate species initially suggested the existence of different cognate receptors 


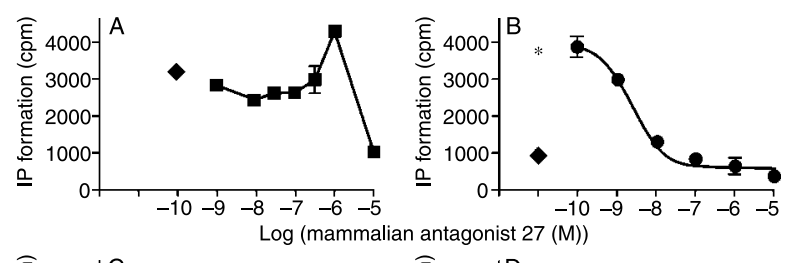

cGnRH-Rs maintain higher ligand selectivity for GnRH-II. This presents a conundrum in that cGnRH-I is the hypothalamic peptide regulating the gonadotroph (Mikami et al. 1988, Sharp et al. 1990). GnRH-II was more potent at stimulating inositol phosphate production at the cGnRH-R-III than cGnRH-I. Similarly, GnRH-II stimulates inositol phosphate production four times more potently at cGnRH-R-I than cGnRH-I, consistent with previous data (Sun et al. 2001b, Shimizu \& Bedecarrats 2006). Since inositol phosphate and diacyl-glycerol are generated by the recruitment of the $\mathrm{Gq}$ protein and activation of PLC- $\beta$ (Stojilkovic et al. 1994, Ruf et al. 2003), cGnRH-R-III can activate the protein kinase $\mathrm{C}$ and $\mathrm{Ca}^{2+}$ second messenger signalling pathways, which are the predominant mediators of LH and FSH biosynthesis and secretion (Conn \& Crowley 1994, Sealfon et al. 1997). However, receptor ligand selectivity measured in vitro does not necessarily correlate with in vivo functional significance nor does it determine the designation of cognate receptors. Maybe evolutionary recruitment of ligand-receptor pairing for particular physiological processes is not determined by selection according to the highest affinity for ligand binding or efficacy in inositol phosphate production.

Considering differences between the two chicken receptors, the possibility that cGnRH-R-III may differ from $c G n R H-R-I$ in the rate of ligand-induced internalisation was anticipated because eight additional residues occur in the carboxyl-terminal tail of cGnRH-R-III, a domain that predisposes GnRH-Rs to rapid rates of internalisation (Pawson et al. 1998). A slightly greater rate of internalisation was measured for cGnRH-R-III compared with cGnRH-R-I. The region crucial for receptor internalisation of cGnRH-R-I is distal residue 336 in cGnRH-R-I (Pawson et al. 1998). In cGnRH-R-III, this region contains all eight of the additional residues that comprise the elongated tail. The spatial arrangement of amino acid residues in the carboxyl-terminus region of cGnRH-R-III may contribute to the increase in internalisation rate, given that the known residues important for internalisation are conserved between the two receptors (Pawson et al. 1998, 2003; Fig. 1A).

Both cGnRH-R-III and cGnRH-R-I have a significantly higher binding affinity for mammalian antagonist 27 compared with mammalian antagonists 135-18 and 135-25. GnRH-R-I showed a 56-fold higher binding affinity for antagonist 27 than the binding affinity at cGnRH-R-III. The observed low binding affinities of mammalian antagonists $135-25$ and $135-18$ are translated into similarly low potencies in their capacity to stimulate or inhibit inositol phosphate accumulation. The sizes of these effects are too small to accurately differentiate the two receptor subtypes.

Antagonist 27 showed inverse agonistic effects at both chicken receptors. Differences in binding affinity were translated into differences in antagonistic effects at the receptors, with antagonist 27 showing a 153-fold higher antagonistic effect at cGnRH-R-I than cGnRH-R-III. 
Therefore, it may be possible to utilise antagonist 27 to differentially block type I GnRH receptor function in vivo in order to study type III GnRH receptor physiology.

In summary, we directly compared pharmacological properties of cGnRH-R-I and cGnRH-R-III, and found both receptors to be similar in response to endogenous chicken GnRH ligands. Pharmacological profiling of the type I and type III GnRH receptors has established that GnRH-II is more selective and more potent in inositol phosphate accumulation at both receptors than cGnRH-I. cGnRH-R-III has a more rapid internalisation rate than cGnRH-R-I. Activation and inhibition by GnRH analogues acting on cGnRH-R-I and cGnRH-R-III has been characterised using a range ligands (sGnRH-III, mammalian antagonist 27, 135-18 and 135-25), furthering the pharmacological profile of both receptor subtypes.

The findings concerning ligand selectivity, $G$ protein coupling and internalisation of cGnRH-R-III suggest that it could theoretically function similarly to cGnRH-R-I to regulate gonadotrophin synthesis. However, the predominant levels of cGnRH-R-III mRNA in the pituitary gland (1373fold more than cGnRH-R-I), and the changes in expression patterns with age and sex suggest a distinct functional capacity of cGnRH-R-III compared with cGnRH-R-I.

However, further experiments are required to elucidate the role of cGnRH-R-III within the pituitary. Our studies suggest that evolutionary plasticity in the tissue-specific adoption of GnRH ligand and receptor subtypes for regulation of particular physiological functions may have occurred in birds. Birds appear to have adopted a strategy to regulate gonadotrophin synthesis and release, which utilises cGnRH-I and cGnRH-R-III pairing. The development of GnRH analogues such as antagonist 27 that differentially affect GnRH receptor subtype function will be valuable for determining the physiological roles of different ligands and receptor subtypes.

\section{Declaration of interest}

The authors declare that there is no conflict of interest that could be perceived as prejudicing the impartiality of the research reported.

\section{Funding}

The research was funded by a BBSRC Studentship ( $\mathrm{N} \mathrm{J}$ ) and the Medical Research Council (K M and R P M).

\section{Acknowledgements}

We thank Dr R W Roeske (Indiana University, Indianapolis) for providing the mammalian antagonists. We thank Dr Adam Pawson for advising on receptor internalisation studies, Dr Zhi-Liang Lu for advice on IP assays and Nicola Miller for technical expertise. We thank Professor Peter Sharp and Dr Alan Stewart for helpful discussions.

\section{References}

Ballesteros J, Kitanovic S, Guarnieri F, Davies P, Fromme BJ, Konvicka K, Chi L, Millar RP, Davidson JS, Weinstein H et al. 1998 Functional microdomains in g-protein-coupled receptors - the conserved arginine-cage motif in the gonadotropin-releasing hormone receptor. Journal of Biological Chemistry 273 10445-10453.

Berg KA, Clarke WP, Sailstad C, Saltzman A \& Maayani S 1994 Signal-transduction differences between 5-hydroxytryptamine type $2 \mathrm{~A}$ and type 2C receptor systems. Molecular Pharmacology 46 477-484.

Berridge MJ, Dawson RMC, Downes CP, Heslop JP \& Irvine RF 1983 Changes in the levels of inositol phosphates after agonist-dependant hydrolysis of membrane phosphoinositides. Biochemical Journal 212 473-482.

Bruggeman V, Onagbesan O, Vanmontfort D, Berghman L, Verhoeven G \& Decuypere E 1998 Effect of long-term food restriction on pituitary sensitivity to CLHRH-I in broiler breeder females. Journal of Reproduction and Fertility 114 267-276.

Chou HF, Johnson AL \& Williams JB 1985 Luteinizing-hormone releasing activity of [Gln8]-LHRH and [His5, Trp7, Tyr8]-LHRH in the cockerel, in vivo and in vitro. Life Sciences 37 2459-2465.

Conn PM \& Crowley WF 1994 Gonadotropin-releasing-hormone and its analogs. Annual Review of Medicine 45 391-405.

Davidson JS, McArdle CA, Davies P, Elario R, Flanagan CA \& Millar RP $1996 \mathrm{Asn}(102)$ of the gonadotropin releasing hormone receptor is a critical determinant of potency for agonists containing C-terminal glycinamide. Journal of Biological Chemistry 271 15510-15514.

Dunn IC, Lewis PD, Wilson PW \& Sharp PJ 2003 Acceleration of maturation of FSH and LH responses to photostimulation in prepubertal domestic hens by oestrogen. Reproduction 126 217-225.

Flanagan CA, Becker II, Davidson JS, Wakefield IK, Zhou W, Sealfon SC \& Millar RP 1994 Glutamate-301 of the mouse gonadotropin-releasinghormone receptor confers specificity for arginine- 8 of mammalian gonadotropin-releasing-hormone. Journal of Biological Chemistry 269 22636-22641.

Flanagan CA, Fromme BJ, Davidson JS \& Millar RP 1998 A high affinity gonadotropin-releasing hormone $(\mathrm{GnRH})$ tracer, radioiodinated at position 6, facilitates analysis of mutant GnRH receptors. Endocrinology 139 4115-4119.

Flanagan CA, Zhou W, Chi L, Yuen T, Rodic V, Robertson D, Johnson M, Holland P, Millar RP, Weinstein H et al. 1999 The functional microdomain in transmembrane helices 2 and 7 regulates expression, activation, and coupling pathways of the gonadotropin-releasing hormone receptor. Journal of Biological Chemistry 274 28880-28886.

Flanagan CA, Rodic V, Konvicka K, Yuen T, Chi L, Rivier JE, Millar RP, Weinstein H \& Sealfon SC 2000 Multiple interactions of the Asp(2.61(98)) side chain of the gonadotropin-releasing hormone receptor contribute differentially to ligand interaction. Biochemistry 39 8133-8141.

Flanagan CA, Chen C-C, Coetsee M, Mamputha S, Whitlock KE, Bredenkamp N, Grosenick L, Fernald RD \& Illing N 2007 Expression, structure, function, and evolution of gonadotropin-releasing hormone (GnRH) receptors GnRH-R1SHS and GnRH-R2PEY in the teleost, Astatotilapia burtoni. Endocrinology 148 5060-5071.

Hattori A, Ishii S \& Wada M 1986 Effects of 2 kinds of chicken luteinizinghormone-releasing hormone (LHRH), mammalian LHRH and its analogs on the release of LH and FSH in Japanese-quail and chicken. General and Comparative Endocrinology 64 446-455.

Ikemoto T \& Park MK 2007 Comparative analysis of the pituitary and ovarian $\mathrm{GnRH}$ systems in the leopard gecko: signaling crosstalk between multiple receptor subtypes in ovarian follicles. Journal of Molecular Endocrinology $\mathbf{3 8}$ 289-304.

Illing N, Troskie BE, Nahorniak CS, Hapgood JP, Peter RE \& Millar RP 1999 Two gonadotropin-releasing hormone receptor subtypes with distinct ligand selectivity and differential distribution in brain and pituitary in the goldfish (Carassius auratus). PNAS 96 2526-2531. 
Joseph NT, Sellar R, Morgan K, Millar RP \& Dunn IC 2006 A novel chicken gonadotrophin releasing hormone receptor: expression, binding affinity and functional activity. 23rd Conference of European Comparative Endocrinologists. 6657.

King JA \& Millar RP 1995 Evolutionary aspects of gonadotropinreleasing-hormone and its receptor. Cellular and Molecular Neurobiology 15 5-23.

Krishnan KA, Proudman JA, Bolt DJ \& Bahr JM 1993 Development of an homologous radioimmunoassay for chicken follicle-stimulating-hormone and measurement of plasma FSH during the ovulatory cycle. Comparative Biochemistry and Physiology. Part A, Physiology 105 729-734.

Liu RC, Lea RW \& Sharp PJ 1995 Sexually differentiated role of calcium ions in chicken GnRH-I-stimulated release of LH from anterior pituitary glands from adult domestic chickens. General and Comparative Endocrinology 100 267-272.

Maney DL, Richardson RD \& Wingfield JC 1997 Central administration of chicken gonadotropin-releasing hormone-II enhances courtship behavior in a female sparrow. Hormones and Behavior 32 11-18.

Mikami S, Yamada S, Hasegawa Y \& Miyamoto K 1988 Localization of avian LHRH-immunoreactive neurons in the hypothalamus of the domesticfowl, Gallus domesticus, and the Japanese quail, Coturnix coturnix. Cell and Tissue Research 251 51-58.

Millar RP 2005 GnRHs and GnRH receptors. Animal Reproduction Science 88 5-28.

Millar RP, Milton RCD, Follett BK \& King JA 1986 Receptor-binding and gonadotropin-releasing activity of a novel chicken gonadotropin-releasinghormone ([His5, Trp7, Tyr8] GnRH) and a D-Arg6 analog. Endocrinology 119 224-231.

Millar RP, Lu ZL, Pawson AJ, Flanagan CA, Morgan K \& Maudsley SR 2004 Gonadotropin-releasing hormone receptors. Endocrine Reviews 25 235-275.

Moncaut N, Somoza G, Power DM \& Canario AVM 2005 Five gonadotrophin-releasing hormone receptors in a teleost fish: isolation, tissue distribution and phylogenetic relationships. Journal of Molecular Endocrinology 34 767-779.

Morgan K \& Millar RP 2004 Evolution of GnRH ligand precursors and $\mathrm{GnRH}$ receptors in protochordate and vertebrate species. General and Comparative Endocrinology 139 191-197.

Myburgh DB, Millar RP \& Hapgood JP 1998 Alanine-261 in intracellular loop III of the human gonadotropin-releasing hormone receptor is crucial for G-protein coupling and receptor internalization. Biochemical Journal 331 893-896.

Pawson AJ, Katz A, Sun YM, Lopes J, Illing N, Millar RP \& Davidson JS 1998 Contrasting internalization kinetics of human and chicken gonadotropinreleasing hormone receptors mediated by C-terminal tail. Journal of Endocrinology 156 R9-R12.

Pawson AJ, Maudsley SR, Lopes J, Katz AA, Sun YM, Davidson JS \& Millar RP 2003 Multiple determinants for rapid agonist-induced internalization of a nonmammalian gonadotropin-releasing hormone receptor: a putative palmitoylation site and threonine doublet within the carboxyl-terminal tail are critical. Endocrinology 144 3860-3871.

Pelle R \& Murphy NB 1993 Northern hybridization-rapid and simple electrophoretic conditions. Nucleic Acids Research 21 2783-2784.

Pfleger KDG, Bogerd J \& Millar RP 2002 Conformational constraint of mammalian, chicken, and salmon GnRHs, but not GnRH II, enhances binding at mammalian and nonmammalian receptors: evidence for preconfiguration of GnRH II. Molecular Endocrinology 16 2155-2162.

Proudman JA, Scanes CG, Johannsen SA, Berghman LR \& Camp MJ 2006 Comparison of the ability of the three endogenous GnRHs to stimulate release of follicle-stimulating hormone and luteinizing hormone in chickens. Domestic Animal Endocrinology 31 141-153.

Ruf F, Fink MY \& Sealfon SC 2003 Structure of the GnRH receptorstimulated signaling network: insights from genomics. Frontiers in Neuroendocrinology 24 181-199.

Sealfon SC, Weinstein H \& Millar RP 1997 Molecular mechanisms of ligand interaction with the gonadotropin-releasing hormone receptor. Endocrine Reviews 18 180-205.

Sharp PJ \& Ciccone NA 2005 The gonadotrophin releasing hormone neurone: key to avian reproductive function. In Functional Avian Endocrinology, pp 59-72. Eds A Dawson \& PJ Sharp. India: Narosa Publishing House Pvt Ltd.
Sharp PJ, Sterling RJ, Milton RCD \& Millar RP 1986 Effect of luteinizinghormone-releasing hormone and its analogs on plasma luteinizing-hormone concentrations in incubating bantam hens. British Poultry Science 27 129-135.

Sharp PJ, Dunn IC \& Talbot RT 1987 Sex-differences in the LH responses to chicken LHRH-I and LHRH-II in the domestic-fowl. Journal of Endocrinology 115 323-331.

Sharp PJ, Talbot RT, Main GM, Dunn IC, Fraser HM \& Huskisson NS 1990 Physiological roles of chicken LHRH-I and LHRH-II in the control of gonadotropin-release in the domestic chicken. Journal of Endocrinology 124 291-299.

Shimizu M \& Bedecarrats GY 2006 Identification of a novel pituitary-specific chicken gonadotropin-releasing hormone receptor and its splice variants. Biology of Reproduction 75 800-808.

Sreekumar KP \& Sharp PJ 1998 Ontogeny of the photoperiodic control of prolactin and luteinizing hormone secretion in male and female bantams (Gallus domesticus). General and Comparative Endocrinology 109 69-74.

Stojilkovic SS, Reinhart J \& Catt KJ 1994 Gonadotropin-releasing-hormone receptors - structure and signal-transduction pathways. Endocrine Reviews $\mathbf{1 5}$ 462-499.

Sun YM, Dunn IC, Baines E, Talbot RT, Illing N, Millar RP \& Sharp PJ $2001 a$ Distribution and regulation by oestrogen of fully processed and variant transcripts of gonadotropin releasing hormone I and gonadotropin releasing hormone receptor mRNAs in the male chicken. Journal of Neuroendocrinology 13 37-49.

Sun YM, Flanagan CA, Illing N, Ott TR, Sellar R, Fromme BJ, Hapgood J, Sharp P, Sealfon SC \& Millar RP $2001 b$ A chicken gonadotropin-releasing hormone receptor that confers agonist activity to mammalian antagonists - identification of D-Lys(6) in the ligand and extracellular loop two of the receptor as determinants. Journal of Biological Chemistry 276 7754-7761.

Tello JA, Wu S, Rivier JE \& Sherwood NM 2008 Four functional GnRH receptors in zebrafish: analysis of structure, signaling, synteny and phylogeny. In Integrative and Comparative Biology, pp 570-587. San Antonio, TX, USA.

Troskie BE, Hapgood JP, Millar RP \& Illing N 2000 Complementary deoxyribonucleic acid cloning, gene expression, and ligand selectivity of a novel gonadotropin-releasing hormone receptor expressed in the pituitary and midbrain of Xenopus laevis. Endocrinology 141 1764-1771.

Vangils J, Absil P, Grauwels L, Moons L, Vandesande F \& Balthazart J 1993 Distribution of luteinizing-hormone-releasing hormones-I and hormonesII (LHRH-I and LHRH-II) in the quail and chicken brain as demonstrated with antibodies directed against synthetic peptides. Journal of Comparative Neurology 334 304-323.

Wang L, Bogerd J, Choi HS, Seong JY, Soh JM, Chun SY, Blomenrohr M, Troskie BE, Millar RP, Yu WH et al. 2001 Three distinct types of GnRH receptor characterized in the bullfrog. PNAS 98 361-366.

Wilson SC, Chairil RA, Cunningham FJ \& Gladwell RT 1990 Changes in the hypothalamic contents of LHRH-I and LHRH-II and in pituitaryresponsiveness to synthetic chicken LHRH-I and LHRH-II during the progesterone-induced surge of LH in the laying hen. Journal of Endocrinology 127 487-496.

Yushmanov SV \& Chumakov KM 1988 Algorithms for the construction of phylogenetic trees with maximum topology similarity. Molekulyarnaya Genetika, Mikrobiologiya i Virusologiya 3 9-15.

Zhou W, Flanagan C, Ballesteros JA, Konvicka K, Davidson JS, Weinstein H, Millar RP \& Sealfon SC 1994 A reciprocal mutation supports helix 2 and helix 7 proximity in the gonadotropin-releasing hormone receptor. Molecular Pharmacology 45 165-170.

Zhou W, Rodic V, Kitanovic S, Flanagan CA, Chi L, Weinstein H, Maayani S, Millar RP \& Sealfon SC 1995 A locus of the gonadotropin-releasinghormone receptor that differentiates agonist and antagonist binding-sites. Journal of Biological Chemistry 270 18853-18857.

\section{Received in final form 26 March 2009 \\ Accepted 20 April 2009 \\ Made available online as an Accepted Preprint 20 March 2009}

